IRSTI 06.61.33

UDK 33.332 .12

https://doi.org/10.46914/1562-2959-2021-1-3-28-32

\author{
S.S. TLEUBERDIYEVA, ${ }^{1 *}$ \\ $\mathrm{PhD}$, associate professor. \\ *e-mail: tleuberdieva@yandex.ru \\ R.S. MUSSINA, ${ }^{2}$ \\ c.e.s., associate professor deputy. \\ e-mail: rashka7878@mail.ru
}

A.B. MOLDASHEVA, ${ }^{3}$

c.e.s., associate professor. e-mail: altun_78@mail

G.S. KODASHEVA, ${ }^{1}$

$\mathrm{PhD}$.

e-mail: kodasheva@mail.ru

${ }^{1}$ L.N. Gumilyov Eurasian National University,

Kazakhstan, Nur-Sultan

${ }^{2}$ S. Seifullin Kazakh AgroTechnical University

Kazakhstan, Nur-Sultan

${ }^{3}$ M.Kh. Dulaty Taraz Regional University

Kazakhstan, Taraz

\title{
REGIONAL UNEMPLOYMENT AND STATE EMPLOYMENT REGULATION
}

\begin{abstract}
The purpose of the article is to study a unique and planned sphere of life of social and economic society in the regional labor market. As it also covers the market of workforce directly connected to production, the concepts unemployment and workplace safety are important. The loss of work means low quality of life and the instability of the economy for many people. Employment determines the content of important aspects of social development to meet the needs of people in the labor market. The article emphasizes that the main policy of the state in regulating the labor market is the implementation of an employment policy for the entire population that preserves the natural level of employment, does not allow the emergence of cyclical employment, the formation of a "flexible market" that quickly adapts to internal and external changes, allowing to maintain stability and management. This compared to the traditional market creates conditions for flexible employee management in conditions of incomplete working day, temporary employment, replacement. On this flexible market, every citizen, looking for work, is obliged to find a workplace that meets its requests. In the labor market, public policy goes in two directions. Active training and retraining in order to create new jobs, ensuring employment and deliverance from unemployment. This can include events implemented in the framework of programs in our country. Passive is support for unoccupied citizens by providing social benefits. The main methods applied by the state in providing regional employment include stimulating investment in the economy, depending on the specifics of each region, which is the main condition for creating new jobs.
\end{abstract}

Key words: region, unemployment, state, regulation, efficiency policy, labor force, payments, support.

\section{Introduction}

Unemployment is an important element of a market economy that creates excessive reserves of labor that can optimally respond to consumer demand. Its level has stable, developed countries with normal and annually show a positive indicator, such as Kazakhstan, in slowly growing, economically, increased and unstable. Consequently, such unemployment includes policies to protect the rights of unemployed by developing employment programs in developing countries. 


\section{Fundamental rules}

Orders, rules, regulations, provisions and governments of foreign and domestic scientists for regional unemployment and employment regulation, as well as orders, rules and governments and governments of the Republic of Kazakhstan and decrees, in the details of the Statistical Committee of the Republic of Kazakhstan, the largest program "Roadmap 2020" , covering the regions of Kazakhstan, in the legislation of "Employment", "to work", "state targeted social assistance".

\section{Literature review}

The theoretical base of the article is S. Fisher, R. Dornbush, R. Shmalensky, A.I. Beksultanova, M.T. Azimova, A.V. Ashurgina and others. It works.

\section{Materials and methods}

The results of each region in the distribution of zones that provide the level of the state as a whole. In this regard, Kazakhstan has formed the main areas of regional employment policies. In order to ensure employment, the state pursues two different policies in the regions. They are active and passive policies to combat unemployment.

We reviewed the policy of state employment regulation using theoretical methods for studying the title of the article. Employment Efficiency Policy is economic activities carried out by the state to eliminate unemployment. In the fight against unemployment, the character turns off to active events in passive measures.

Inactive policies are a policy to regulate the negative effects of unemployment (state nominal payments, financial assistance, financial assistance), aimed at ensuring unemployment. Political policy is considered as a priority level of employment. Active regulations include measures to create conditions for the coverage of the state, increase the number of jobs, and have a positive impact on the skills of labor. In this case, the employment service should help reduce the army of the unemployed.

Using the analysis method, we are considering the areas of state policy in the field of regional labor development:

- ensuring the free choice of the free choice of citizens without citizenship, citizens of Kazakhstan, foreign citizens and citizens permanently residing in the country, fair and favorable working conditions, social unemployment;

- effective occupation of the population of the region, reducing unemployment, the formation of positions;

- focus on training personnel in accordance with the needs of the market and its development, given the investment policy in the regions;

- assistance in developing business entrepreneurship initiatives at the regional level at the regional level, the development of productive, creative work;

- encouraging support for previous employers and create new jobs in target groups;

- protection of the domestic labor market through the import quota in other countries;

- a set of republican measures in the field of employment with measures taken by bodies in the region;

- coordination of activities in the field of work with other regions in the field of economic, social policy;

- ensuring the participation of employers, employees of workers and publications in the implementation of public employment;

- conducting employment policies, which supports the creation of additional jobs in financial, tax and investment policies.

The state provides for measures to help target groups of the population.

Local executive bodies may form an additional list of people: associated with target groups based on the situation in the labor market and the budget, as well as people in social protection.

The purpose of the state employment policy is to promote employment with full, fruitful, efficient and free chosen people.

The state employment policy includes the policy of formation of demand for labor, the policy of formation of human resources, demand for employees and the policy of balanced impact on demand. 


\section{Results}

State guarantees of social support for unemployed in the region:

- Free vocational guidance, training, retraining and advanced training in the field of employment;

- Free medical care and expertise;

- Possibility to take part in public services on a paid basis;

- Reimbursement of expenses related to the voluntary transfer of employment to another settlement to the management of the labor body;

- Provision of social assistance in the form of unemployment benefits, scholarships (during registration), one-time payments and other types of material assistance (subsidies to social benefits, transport, transport, preschool institutions).

Employment management is carried out by state and regional bodies on the basis of macro and microeconomic indicators of social and labor sectors and its basic parameters - labor and job analysis.

There is a regional classification criteria for the creation of jobs, workplaces of people with disabilities, youth, women's and women's etc. - employees, workers and students, etc. is to divide. Workplaces in addition to the workplace of work and investment elimination (rental workers and entrepreneurs, entrepreneurs can be classified by the new level of work (public, seasonal), the new level of production process.

\section{Discussions}

A set of measures to create progressive and creating new jobs in the region, the set of measures to create progressive and creating new jobs in the region is included in the investment program to implement the following strategies:

- formation of the workplace market, taking into account regional and industry factors.

- Increasing investment activity to create new jobs in the field of small business and selfemployment, expanding the flexible labor market sector, creating favorable investment conditions for domestic and foreign investors.

- coordination of existing and new jobs on the economic complex of the region due to the demographic and professional structure of the population.

- Development of a system of specialized jobs aimed at improving the material conditions of workers and improving the working conditions, increasing the material conditions of the region and the amount of services and services of the region.

- Improving the quality of work on the development of continuing professional education.

The task of the system of employment is explained by the control of the implementation of jobs as a tool to provide employment of workplaces as a tool to manage employment, limited labor and jobs, restricts the increase in labor and external migration.

\section{Conclusion}

In conclusion, the issues arising in connection with the specifics of the labor market in the region will still require the improvement of public policy at the region. In particular, unemployment between the unemployment between the unemployment, the education of the market, the direction of the main migration flow to the regional center leads to all interregional issues, not only at the city level. In the Republic of Kazakhstan, various programs have been developed to provide people to work and implement them. The work carried out under the programs must be monitored and regulated by the state.

\section{REFERENCES}

1 Resolution of the Government of the Republic of Kazakhstan dated. - December 29, 2016, on approval of the "Program of Effective Employment and Mass Development Development for 2017-2021". URL: http:// www.adilet.zan.kz/

2 Problems with essentially illustrants, PB Murzakarimova, Politics-Policy. - Almaty, No. 12, 2017. 
3 Shaimerdinova A.S. Motivation and stimuli. - Polyovoye-Politics. - No. 9, 2017.

4 http: /kyzylorda.gov.kz Website of Kyzylorda city akimat.

5 Charter "Employment Center of Kyzylorda".

6 Ministry of Labor and Social Protection of the Republic of Kazakhstan. - URL: http://www.enbek. gov.kz

7 Internal regulations of the Kyzylorda Center for the Employment Center.

8 Description of the "Employment 2020 Program", B.Ague. URL: https://www.massaget.kz/

9 Statistical information "Department of employment and social programs of Kyzylorda city". URL: http://www.kyzylorda.gov.kz

10 Statistical information "Department of Kyzylorda city employment and social programs". URL: http:// www.kyzylorda.gov.kz

\author{
С.С. ТЛЕУБЕРДИЕВА, *1 \\ $\mathrm{PhD}$, доцент. \\ *e-mail: tleuberdieva@yandex.ru \\ P.С. МУСИНА, ${ }^{2}$ \\ э.ғ.к., қауымдастырылған профессор м.а. \\ e-mail: rashka7878@mail.ru \\ А.Б. МООЛДАШЕВА, ${ }^{3}$ \\ e-mail: э.ғ.к., доцент. \\ e-mail: altun788@mail.ru \\ Г.С. КОДАШЕВА, ${ }^{1}$ \\ $\mathrm{PhD}$. \\ e-mail: kodasheva@mail.ru \\ ${ }^{1}$ Л.Н. Гумилев атындағы Еуразия ұлттық университеті, \\ Казақстан, Нұр-Сұлтан қ. \\ ${ }^{2}$ С. Сейфуллин атындағы Қазақ агротехникалық университеті, \\ Қазақстан Нұр-Сұлтан қ. \\ ${ }^{3}$ М.X. Дулати атындағы Тараз өңірлік университеті \\ Қазақстан, Тараз қ.
}

\title{
ҰЙЫМДАҒЫ КАПИТАЛДЫ БАСКАРУДЫН ТЕОРИЯЛЫҚ НЕГІЗДЕРІ ЖӘНЕ ЖЕТІЛДІРУ ЖОЛДАРЫ
}

\begin{abstract}
Андатпа
Мақаланың мақсаты - аймақтық еңбек нарығындағы әлеуметтік-экономикалық қоғам өмірінің ерек әрі жоспарлы сферасын зерттеу. Сонымен қатар, өндіріске тікелей қатысатын еңбек нарығын қамтығандықтан, жұмыссыздық пен еңбек қауіпсіздігі ұғымдары маңызды. Жұмыстан айырылу көптеген адамдар үшін өмір сүру сапасының төмендігі мен экономиканың тұрақсыздығын білдіреді. Жұмысбастылық адамдардың еңбек нарығындағы мұқтаждықтарын қанағаттандыру бойынша танылатын әлеуметтік дамудың маңызды аспектілерінің мазмұнын айқындайды. Еңбек нарығын реттеудегі мемлекеттің негізгі саясатына табиғи жұмысбастылық деңгейін сақтайтын, циклдық жұмысбастылықтың орын алуына жол бермейтін, барлық халықты жұмыспен қамтитын саясат жүргізу, тұрақтылық пен басқаруды сақтауға мүмкіндік беретін, ішкі және сыртқы өзгерістерге тез бейімделетін «икемді нарық» қалыптастыру екені мақалада баса айтылған. Бұл дәстүрлі нарықпен салыстырғанда жұмысшыларды толық емес еңбек күнінде, уақытша жұмысбастылық, ауысым бойынша жұмыс істеген уақытта икемді басқаруға жағдай жасайды. Бұндай икемді нарықта әрбір жұмыс іздеуші азамат өзінің сұранысына сай келетін жұмыс орнын табуға міндетті. Еңбек нарығында мемлекеттік саясат екі бағытта жүреді. Жаңа жұмыс орындарын құру, жұмыспен қамтуды қамтамасыз ету және жұмыссыздықтан арылу мақсатында белсенді оқыту және қайта оқыту. Бұған біздің елімізде бағдарламалар аясында жүзеге асырылатын іс-шаралар кіреді. Енжар - жұмысы жоқ азаматтарды әлеуметтік төлемдер беру арқылы қолдау болып табылады. Аймақтық жұмысбастылықты қамтамасыз етудегі мемлекет қолданатын негізгі әдістеріне жаңа жұмыс орындарын құрудың басты шарты болып табылатын, әрбір аймақтың ерекшелігіне байланысты экономикаға инвестиция тартуды ынталандыру жатады.
\end{abstract}

Тірек сөздер: аймақ, жұмыссыздық, мемлекет, реттеу, тиімділік саясаты, жұмыс күші, төлемдер, қолдау. 
С.С. ТЛЕУБЕРДИЕВА, ${ }^{1 *}$

$\mathrm{PhD}$, доцент.

*e-mail: tleuberdieva@yandex.ru

P.С. МУСИНА, ${ }^{2}$

к.э.н., и.о. ассоциированный профессор.

e-mail: rashka7878@mail.ru

А.Б. МОЛЛДАШЕВА, ${ }^{3}$

к.э.Н., доцент.

e-mail: altun78@@mail.ru

Г.С. КОДАШЕВА, ${ }^{1}$

$\mathrm{PhD}$.

e-mail: kodasheva@mail.ru

${ }^{1}$ Евразийский национальный университет Л.Н. Гумилева,

Казахстан, г. Нур-Султан

${ }^{2}$ Казахский агротехнический университет им. С. Сейфуллина,

Казахстан, г. Нур-Султан

${ }^{3}$ Таразский региональный университет им. М.Х. Дулати,

Казахстан, г. Тараз

\title{
РЕГИОНАЛЬНАЯ БЕЗРАБОТИЦА \\ И ГОСУДАРСТВЕННОЕ РЕГУЛИРОВАНИЕ ЗАНЯТОСТИ
}

\begin{abstract}
Аннотация
Целью статьи является изучение специфики и планируемых сфер жизнедеятельности социально-экономического общества на региональном рынке труда. Поскольку он также охватывает рынок труда, который непосредственно участвует в производстве, важны понятия безработицы и безопасности труда. Потеря работы означает низкое качество жизни и нестабильную экономику для многих людей. Занятость определяет содержание важнейших аспектов общественного развития, общепризнанных с точки зрения удовлетворения потребностей людей на рынке труда. В статье подчеркивается, что основной политикой государства в регулировании рынка труда является проведение политики занятости всего населения, сохраняющей естественный уровень занятости, не допускающей возникновения циклической занятости, формирование «гибкого рынка», быстро адаптирующегося к внутренним и внешним изменениям, позволяющего сохранить стабильность и управление. Это по сравнению с традиционным рынком создает условия для гибкого управления работниками в условиях неполного рабочего дня, временной занятости, сменности. На таком гибком рынке каждый гражданин, ищущий работу, обязан найти рабочее место, отвечающее его запросам. Отмечается, что на рынке труда государственная политика идет в двух направлениях. Активное обучение и переобучение с целью создания новых рабочих мест, обеспечения занятости и избавления от безработицы. К этому можно отнести мероприятия, реализуемые в рамках программ в нашей стране. Пассивной является поддержка незанятых граждан путем предоставления социальных выплат. К основным методам, применяемым государством в обеспечении региональной занятости, относится стимулирование привлечения инвестиций в экономику в зависимости от специфики каждого региона, что является главным условием создания новых рабочих мест.
\end{abstract}

Ключевые слова: регион, безработица, государство, регулирование, политика эффективности, рабочая сила, платежи, поддержка. 